Portland State University

PDXScholar

Empowering the Voice of the Female Student: A

Gender Inclusive Approach to the High School

Language Arts Curriculum

Brittany Bonnet

Portland State University

Follow this and additional works at: https://pdxscholar.library.pdx.edu/honorstheses

Let us know how access to this document benefits you.

Recommended Citation

Bonnet, Brittany, "Empowering the Voice of the Female Student: A Gender Inclusive Approach to the High School Language Arts Curriculum" (2015). University Honors Theses. Paper 129.

https://doi.org/10.15760/honors.149

This Thesis is brought to you for free and open access. It has been accepted for inclusion in University Honors Theses by an authorized administrator of PDXScholar. Please contact us if we can make this document more accessible: pdxscholar@pdx.edu. 


\title{
Empowering the Voice of the Female Student: A Gender Inclusive Approach to the High School Language Arts Curriculum
}

\author{
By: \\ Brittany Bonnet
}

An undergraduate honors thesis submitted in partial fulfillment of the requirements of:

Bachelor of Arts

in

University Honors

and

English

Thesis Adviser:

Sarah Ensor Ph.D.

Portland State University 


\section{Acknowledgements:}

I would like to thank all the of Portland State professors who have helped me with this project; Prof. David Wolf, whose personal experiences and knowledge helped get this project off the ground running, Prof. Anne Marie Fallon, who served as a task manager and provided encouragement while I completed this task, and Prof. Sarah Ensor, whose invaluable feedback made this project the best it could be.

I would also like to thank my friends and family, all of whom helped immensely with this project (whether they knew it or not). Particularly I would like to acknowledge, my mom, Michele, for the long phone calls and encouraging words over the past year, and my best friend Ryann, across from whom I finished this project in many marathon work sessions in countless coffee shops across the city of Portland. 
Abstract:

In American schools, young women are routinely provided with examples of strong male characters and authors in the high school English classroom. Written curriculum (such as the syllabus, reading list, and grading practices) continues to contribute to the erasure of the female student. Furthermore, hidden curriculum (lessons that are taught "unintentionally" such as norms or values), such as a teacher's use of gendered language, or time spent with students of different genders, reflects this same problem as teachers unintentionally disempower the female voice in the classroom. The result is female students who are less confident in the classroom and the workplace later in life. To combat this issue, I present an alternative to the traditional English curriculum that is more gender inclusive and empowering. The syllabus will include not only suggestions for literature, but also ideas for leading class discussion, workshops, and assignments that serve to empower the young female student and empower male students with the skills necessary to combat continued gender issues. Should this class be taught, students would finish with a strong understanding of literature, vocabulary, and writing. However, students would also leave the class with a better knowledge of the complex topic of women's rights. Female students would have developed a more confident approach to learning, and a more empowered discourse. 


\section{Introduction:}

The average American student gaining a public school education will read a very similar set of canonical texts in the his or her Language Arts instruction. Students are inundated with $O f$ Mice and Men, Lord of the Flies, and The Great Gatsby. All of these texts are important and have a legacy in American literature, but they have something in common: they each have a male author, and male protagonists. Just as young girls and boys gravitate toward characters they identify with in childhood (for instance, I always wanted to be Belle from Beauty and the Beast because of her love of books) high school students also need characters they can identify with in the literature that is presented to them. The current model seems to forget that women, too, need characters with whom they can align themselves socially, morally, and creatively. While there are many male characters that are read in the high school classroom who are extremely brave, wise, and strong, where are the women who embody these qualities?

Currently, the Common Core presents schools with suggested texts by grade level. For grade 9 , there are nine suggested texts (stories, plays, poetry) that have female authors out of thirty-three suggested texts. This leaves a 3 to 11 ratio of female to male authored texts. While each of these texts has its place in the literary canon (and is certainly significant to the literary world), students are frequently left without examples of female authors or female lead characters.

The Common Core identifies three major benchmarks for mastering reading in grade 9; they are to identify and cite textual evidence, identify literary themes, and be able to summarize the plot of a narrative. Each of these benchmarks is important to the understanding of literature and how to interpret it; however if students are presented with the experience of one gender, how are they meant to use the skills they learn to interpret the world? Currently, according to the 
Lincoln High School (Portland, OR) course guide, freshmen at Lincoln read one text written by a female author in their first year of school, Zora Neale Hurston's Their Eyes Were Watching God (recommended reading from the Common Core guide). At my high school, Tualatin High School, we also read one text written by a woman in my freshman year in 2006, Anthem by Ayn Rand. In Advanced Freshmen English, we read five texts over the course of the year. With only one of those representing a female author, this falls short of even the Common Core reading list's $27 \%$ female author representation. None of the five texts we read presented a female lead character. Through these texts which provide the reader with only male writers and characters, both male and female students are seeing how only one gender "develops over the course of a text." This model does a disservice to both male and female students.

The reasons for studying Language Arts in high school extend beyond the Common Core Standards, however. The development of analytical skills is necessary, but we also study Language Arts to understand the world and develop the interpersonal skills necessary for participating in the adult world. While more emphasis has been placed recently on developing STEM (Science, Technology, Engineering, and Math) subjects for women, it is not productive to in turn ignore the significance of an inclusive English curriculum. Overall, women outperform men in high school average GPA, as well as in graduation rates (Dept of Education, 2009). While a woman is more likely to graduate with a higher GPA than her male counterpart, I question not only the quality of education she received but also her level of self-confidence, as well as her emotional development. While she leaves high school with more academic capital, she is still less likely to be paid as much as her male peers in the same field of study, and she is less likely to be hired in this field. 
The history of women in education has had an impact on the ways that women communicate and are communicated with in an academic setting. This phenomenon dates back to the exclusion of women from public schooling and disallowing women from attending secondary education establishments in the 18th and 19th centuries, up until today, when women are allowed in, but face silencing by peers and teachers (Sadker \& Sadker, 2010). Studies conducted on female college students have shown how their voices are functioning in the classroom. Research has shown that female university students are more likely to be interrupted and more likely to use qualifying language like "I don't know if this is right but..." or "This might be a stupid question but..." (Hancock and Rubin, 2014). This is coupled with the empowerment of the male voice (which has been demonstrated as early as elementary school). Male students are less likely to be corrected when they speak out of turn in class, and are more likely to be called on by instructors when their hand is raised (Sadker \& Sadker).

The disempowerment of the female voice in the high school classroom extends far beyond the literature presented to students, and into the "hidden curriculum" that is often discussed in educational circles. This refers to examples of teachers inadvertently devoting more time to male students, presenting students with examples of success only through the lens of men (The notion of "Founding Fathers" for instance, implies that America was discovered, settled, and created by men), and teachers using exclusive gender pronouns in a disempowering way, such as using "he" to describe a doctor in a hypothetical scenario although the gender is not explicit or relevant. Though these seem like small daily mistakes, I agree with Sadker and Sadker that a lifetime of minor mistakes from teachers has a lasting impact on the student. 
Instruction practices need to be changed in such a way that teachers can minimize these mistakes. Simple changes can be made by instructors in language, mindfulness of time spent with students of any gender, and a systematic approach to promoting equal speaking time to girls and boys. Further, I firmly believe that the gender issue in high schools can be partially alleviated through monitored discussion about gender in the classroom, facilitated by instructors. If teachers are empowered with the tools to discuss gender with their students, their students can become empowered to carry on those discussions outside of the classroom.

Finally, grading practices need to be changed to promote equity. While research on grading practices in high schools has not yet been conducted, links can be made between gender bias in hiring practice and gender bias in grading. A recent study found that gender bias is still prevalent in the workplace. Hiring managers were offered one of two identical resumes for a lab manager position, one with a female name and one with a male name. Overwhelmingly, the male resume was rated as more competent, more hirable, and more qualified than the female candidate (Moss-Racusin, et al, 2014). More research needs to be conducted to determine if these types of gender bias can carry into the high school classroom, but I am suggesting that teachers are not immune to these types of practices, and I hypothesize that research would yield similar results. While girls tend to have overall higher GPAs than boys in school, there is always a risk of bias in a subjective grading field like Language Arts.

A proficiency-based grading model is one place to start to prevent these types of discrepancies as well as to empower students. The proficiency model eliminates the subjective A - F grading model and places more emphasis on mastering various parts of the subject. Rather than placing a number grade on each task (commonly referred to as a "total points" system) 
students are assessed on a spectrum from "Beginning" to "Exceeds." Most schools that use this system offer many opportunities for students to develop from "Beginning" or "Nearly Meets" to "Meets" or "Exceeds." The grading rubric is made explicit to the students so they know what the expectations are for their work. This serves many purposes, but here it eliminates the opportunity for teachers to give low grades to female students based on an expectation that they will perform better. All students are given specific areas in which they are underperforming as well as opportunities to improve. The teacher is no longer a figurehead handing down a grade, but now serves as a learning coach for each student on an individual basis. The proficiency model also empowers students with the opportunity to take ownership of their learning, rather than being concerned with their final number grade.

Changing the curriculum model in just one school would have a large impact on that school's female and male students. By empowering women in the Language Arts classroom, teachers can inspire them to pursue STEM careers, business ventures, and much more. The English classroom seems to be largely ignored because, short of writing skills, there isn't a recognized correlation between what a student learns in Language Arts and how those skills can be applied practically in the "real" world, or how a Language Arts education can translate into financial capital. I would argue that some of the most valuable skills that are taught in the high school curriculum are learned in the English classroom: empathy, interpretation, and inquiry. Each of these skills is brought to bear when reading and analyzing text. The skills learned when studying English carry into each of the other subjects, and into the careers of the average American citizen. In the following body of work, I will identify not only the many nuanced 
aspects of the problem but also offer a solution to the problem with my own gender inclusive curriculum suggestion.

\section{Literature Review:}

Recently, little work has been done in the field of education regarding the erasure of the female voice. In the late 1980's and early 1990's, questions of how to improve the public school experience for women were being raised in large volume. During this time, the feminist movement was in flux as Third Wave feminism began to take the stage. During this time, feminists became interested in how gender functioned outside of binary concepts, and dismissed "essentialist" feminist ideals from Second Wave feminism. Despite these changes, feminists agreed that female students deserved a voice in the classroom and weren't receiving it. Unfortunately, since then we have not seen significant change in the way of trying to empower the female voice in the high school English classroom, and yet the problem persists. Based on the available examples of curriculum in the area, as well as my own experiences in the public school system, it seems to me that the results previous work would be implemented in the classroom. Feminist authors like Carol Gilligan have worked diligently to bring awareness to the topic of gender differences and development, while authors like Delane Bender Slack have worked on developing feminist pedagogy.

While the work that was done in this time period was extremely beneficial to starting a conversation about gender in the classroom and the teacher's role in facilitating gender inclusive teaching, recent data is showing that these ideas have not made an impact on the classroom. One would hope that because there is no current work being done in this field that it is an obsolete 
topic; however, we can see that this is not the case. We are still seeing a disproportionate number of male-authored texts being taught, even in nationally developed programs such as Common Core Curriculum. Students are still experiencing microaggressions in their classrooms and women are still being silenced by both male and female interlocutors. I enter the conversation from a position of action. The research I have found that is recent serves the purpose of proving that a problem exists. I recognize that data on what is happening inside of classrooms is difficult to find. However, there is a significant amount of data on the success of women after high school, as well as how women interact in the social world. The older research I have found serves the purpose of providing the groundwork for solving the problem. Many writers from the 1980's and 1990's already did much of the work of empowering the female voice in schools, the issue is that not enough of it has been implemented in a meaningful way.

Perhaps the most influential text on this topic is Failing at Fairness by Myra and David Sadker (1994). This text provides a doorway into identifying the issue that is female disempowerment in the high school curriculum. Sadker and Sadker provide the reader with empirical and qualitative data to provide insight into the ways in which female students are "cheated" in American public schools. The authors argue that while women do receive the "same" education as men in the form of teachers, textbooks, and resources, they still do not finish school with the same skills, confidence, and mastery that men do. Sadker and Sadker paved the way for the modern look at this problem by providing first-hand, primary research on the topic. Failing at Fairness provides the reader not only with the quantitative data necessary to identify the problem, but also with a wide variety of anecdotal evidence from years of research in the field conducted by the Sadkers and their researchers. This text has served as a spring board 
for many authors who have done research in the pursuit of identifying the existence and the causes of the gender gap in the American public school. Although this text is over 20 years old, many elements of it are still extremely relevant and I have been able to find data to support that the trends they identify in this text are still supported by recent research.

From this starting point, researchers and authors have begun considering what it would mean to correct the problem. Multiple researchers have done independent research on how the administration of a school can help to end gender exclusive behaviors and other transgressions. These authors argue that change can only begin from the administrative perspective of the education system. Principals and counselors can work together to promote empowerment and social justice in the classroom. These solutions range from diversity trainings where administrators can learn new discourse for discuss issues of social justice (Cambron-McCabe, 2005) to how school counselors can prevent African-American high school drop-outs.

Understanding how the administration works with teachers is crucial to my work and these texts will help me identify ways of working with administrators to implement these ideas.

Finally, many researchers and authors have worked on the frontlines trying to find specific solutions to the female empowerment question. In "Writing Women in(to) the Curriculum," Agatucci discusses how lessons in which women write autobiographical stories are empowering to disadvantaged women in low-income schools (1991). Whaley and Dodge discuss how changing the canon of texts can influence female students (1993). Central to my argument, Whaley and Dodge also provide alternatives to the typical male-centric texts taught in public schools. Other texts have been written that actually display the results of teaching a more feminist approach to English in high schools. Bender-Slack employs this approach and explores 
how a feminist literature class was received by students, teachers, and administrators (2009). She describes in detail the many points of debate that were brought up during the development of the class and perfectly responds to each.

What is not addressed in this work is why there is such a significant gap in work on this subject while the problem persists. If the research has determined that there is a problem (and a significant one at that), why haven't teachers and administrators stepped up to correct it? There is a 10 to 20 year gap in the research, with little verifiable or noticeable change in practices. I have found that recent, relevant research exists but only in an extremely specific way. For instance, a general study on gender bias in the classroom has not been conducted recently, but research has been done in the field of linguistics on the female voice (Hancock and Rubin, 2014). There is also a significant amount of work being done currently on the position of women in the adult world regarding communication, the achievement gap, and general gender bias. One can extrapolate that if these issues are significant during and past college, they are also likely to be prevalent in high schools.

I enter this conversation from a position of "starting from scratch." While the work that has already been done may have influenced other scholars and writers in the field, why hasn't it permeated the classrooms? How has this research not made an impact on teachers, administrators, and law makers? The sources I have found seem to suggest that a connection needs to be made between the recent data that demonstrates the challenges that women face in society today, and the changes that were suggested by the early writers on this topic. I hope to bridge this gap by providing an example of changed curriculum. I will draw on old solutions that have not been implemented, and the new data that has been released in recent years. 


\section{Discussion:}

\section{Literature}

The first and potentially most significant portion of this problem is with the literature presented to students in American classrooms. Most students are reading very similar sets of texts across state and district lines. While each of these texts is a key element to the development of student understanding of the literary world, history, and literary interpretation, I argue that there is no reason this can't be done with a more equal representation of the human experience. Both men and women experience American history, so it is important that we demonstrate to students both of these points of view, if not more. There is no reason to deny students access to multiple points of view in the social and historical landscape.

Many may argue that while a higher percentage of female authors would be nice, there simply aren't enough texts to choose from, and if you must choose from the Common Core list of suggested texts, that might be true. However, there are fewer published female authors overall, even in modern day writing. The organization VIDA works each year to count the number of female authors being reviewed in major publications in relation to the number of male authors. What they find consistently each year is that there are more male authors being reviewed each year, and that there are strikingly more male reviewers. While analyzing these statistics, it is important to reflect upon the fact that publishing companies are simply publishing less female work than male work overall. However, when VIDA did work specifically on children's and young adult fiction, they found that the numbers are much more equal than that of other types of published literature. Women nearly dominate the young adult fiction world. This 
is good news for high school teachers looking for modern and relatable work not just for their own curriculum, but for recommendations for outside reading to their students, both male and female.

When working with fiction from the past, however, the numbers are much more grim. In 2012, Commentary Magazine did research on the amount of scholarship there is on various classic American authors. They found that majority of American literary scholarship has been done on Henry James, followed by twenty-four other well-known authors. Of those twenty-four, only five are female authors. Toni Morrison is the most written upon female author, but falls to number eight on the list, the only woman in the top ten (Myers, 2012). What this demonstrates is that the work of American female authors is not only less prevalent, but is also taken less seriously by literary scholars. Despite their large contribution to the literary world, scholarship appears to largely ignore these authors.

So if there are fewer contemporary female writers, and fewer female writers in history, why is it important to increase high school students' exposure to the female author? It is important because this issue is systemic and begins at the root of a child's understanding of the literary world - school. If a student has grown up with little to no exposure to female authors, at what point does the female student learn that she can become a female author? Because female students are rarely presented with examples of great female authors, they have fewer models to emulate if they desire to write. The teacher can do what he or she can to empower the student with these ideas, but in general, real life examples are more compelling. This leads to generation after generation of male authors dominating the literary world and no change in the literary canon over time. 
But it isn't just exposure to the female author that the student needs, it is also exposure to female protagonists that can benefit the female student. Sadker and Sadker say, "Each time a girl opens a book and reads a womanless history, she learns she is worth less" (13). Literature has the unique quality of offering readers with distinct points of view that are often different from his or her own. Currently, it certainly seems that high school students are only receiving literature that stems from one point of view - the male's. Each story told, while historically or socially relevant to everyone, only describes the way $50 \%$ of the population operates in the world. Of Mice and Men tackles topics like friendship, duty, and the Great Depression, but we don't see things from a woman's perspective at all. How is Curly's wife processing her experiences? Similarly, The Great Gatsby is a crucial text on interpreting the past, the American dream, and social hierarchy. However, the line we most remember from a female character, “...that's the best thing a girl can be in this world, a beautiful little fool" (Fitzgerald) only confirms the belief of the time that women will be rewarded for their complacency. Certainly, a novel written from Daisy's perspective would provide a more honest interpretation of her experiences.

The female student needs to literally see the female experience in order to internalize the ways she, herself, would function in various conflicts. Frequently, if the literature does reflect a female character, she is a sidekick, friend, or love interest. Even great novels by female authors don't seem to feature female protagonists. For example, in Anthem by Ayn Rand, a Common Core suggested book, Equality, the male protagonist, falls in love with female supporting character, Liberty. While Liberty is a strong female character, especially considering the fictional world she lives in, Equality is the driving force behind change and progress. Here we 
see an example of how a female student is not given an example of a woman who can inflict change in her world. Although Liberty plays a role in social change, she is still "supporter" of Equality, not necessarily his equal.

Luckily, many schools are beginning to encourage independent reading of texts with female protagonists. The Hunger Games by Suzanne Collins, a popular dystopian novel among teens, features a strong lead character whose will for justice leads her to fight literally for her home and family throughout the trilogy. Many see this character, Katniss, as an excellent example of the strong female lead, and I agree. Katniss not only embodies the traditional sense of "strong" in a dystopian novel as a skilled bow hunter, brave soldier, and fearless leader, but she also demonstrates many "feminine" qualities that Collins brilliantly does not place in competition with her other strengths. Feminist reading lends itself to question what exactly a "feminine" characteristic is, and certainly this is a conversation that can be had in the classroom as well. What does it mean to be "feminine"? She is nurturing to her sister and mother, but also to her fellow competitors in the games. She exhibits the qualities of a woman, at least as women are typically portrayed in literature and media, without compromising the strength of her character overall.

While novels like The Hunger Games are an excellent beginning to a change in literature in favor of a more gender inclusive canon, it is just a beginning. Understandably, historical texts need to be included in high school reading; while we can't change the texts that were written, as educators it is imperative that we supplement more female-centered texts. It is detrimental for students to be blinded from any texts that influence their understanding of the female experience 
for the sake of history. In fact, there are many texts, such as Beloved, that represent historical times that demonstrate the female experience and yet many schools and administrations refuse to include them in their curriculum. Further, history doesn't necessarily lack female-authored texts, but instead lacks attention the texts that were authored by women. Much of the writing that was done by women historically may not have been considered "literature" at all. How can educators work into their curriculum these types of texts (letters, journals, poetry, etc), in order to illustrate not only the fictional female experience in literature, but also the experience of being a female author.

Unfortunately, while texts like The Hunger Games, and others that are empowering to women are often suggested for outside reading, they are more frequently picked up by female students, while male students gravitate towards more traditionally male centered novels about sports, mystery, or war, as well as texts that have a male as the main protagonist (Kohn, 2002) It needs to be the responsibility of educators and administrators to put these texts in the hands of both male and female students in their schools, and yet in many places exactly the opposite is happening. Last year in 2014, at North Bend High School in Oregon, the school's principal walked into an English classroom and asked students to literally relinquish their copies of The Bluest Eye by Toni Morrison (which appears on the list of Common Core suggested texts). Concerned with the graphic images of violence, students were disallowed an opportunity to read this text in an academic setting. Not only is this a perfect example of the erasure of the female voice, but an example of a lack of administrative support to correct the problem.

Unfortunately, graphic images are a necessary part of demonstrating the female experience in many cases. No history teacher would try to teach about the slave trade without 
images of brutality. We couldn't teach about the Civil Rights Movement without images of lynchings, police brutality and other difficult topics. Such is the same with the story of women in American history. How can English teachers instruct on the historical struggle of women (especially African American women) without images of rape and other violence? It is not the responsibility of the author to present the reader with a positive depiction of the female experience if it is not accurate. Students need not be lied to by the literature they read, and educators have a responsibility to relay the truth to their students.

Changing the literature is just the beginning of education reform in favor of female empowerment. Young women need access to characters who inspire them to be the best versions of themselves without help or direction from male characters. Currently, they are receiving few examples of women taking charge of their bodies, their lives, or their communities, all of which can and must be done in order for women to reach their fullest potential in this society. The outside influences that are holding women back in society will not be broken down if women are not explicitly shown that they can do so. Literature has proven to have the power to incite great change in this country; it can begin in our classrooms.

\section{Voice:}

The United States has a history of exclusion when it comes to public schooling. From its founding in the 18th century, Colonial America excluded women from even the most basic forms of education. Most students of the time received what we would now call a kindergarten level education. Women and slaves were both primarily disallowed from learning in what were considered public schools of the time. However, in the 19th century, major changes were made 
in the efforts of including women in education. More and more teachers were needed to educate the children, and those roles were most often filled by women, who needed to be educated themselves. Of course, this still excluded the education of black citizens in most cases. Even into the 20th century women and other minority groups were denied access into the public school system, with a large swath of laws being passed in near the end of the century to begin to correct the issue.

While it is now common to see both women and minorities learning along side their white male counterparts, there is clearly a history of oppression that needs to be undone. The changes made in education in favor of the inclusion of women were made relatively recently in the history of public education, so naturally there is still work to be done. It has not been demonstrated yet to women that they deserve to have a voice in the classroom. In fact, the argument almost feels like women had to earn their place in the classroom while men were given access to this right. The passing of Title IX in 1972 was necessary only because of the challenges that women faced in an educational setting historically. Basic rights to equal opportunity should not need to be federally mandated, but yet that is what women and minorities have seen time and time again is necessary. So how do women begin to integrate their voices into the classroom in a way that doesn't seem strange or unnatural for them to speak out?

I was interested in how the topic of the female voice was being looked at academically, and was pleased to find that work is being done in this field. Research at George Washington University has demonstrated that women are more likely to be interrupted by both men and women than men (Hancock \& Rubin, 2014). Naturally, this phenomenon carries on into the classroom, particularly in the high school classroom where male students begin to be more 
confident in themselves and women become less and less self-confident. Sadker and Sadker also found that in the demonstrations of male students interrupting female students (sometimes even their instructor), teachers are far less likely to correct a male student than a female one when they speak out of turn. They cite, "Reinforced for passivity, [girls'] independence and self-esteem suffer" (43-44). The argument from educators, particularly in the humanities like Language Arts and History, is that male students are far less likely to participate in class discussion. Teachers are attempting to develop the self-esteem of these male students who are not confident in the humanities, but as a result are stifling the development of the female students. Whether or not male students are less likely to participate in this capacity, I argue that the solution to a lack of meaningful participation from men is not to encourage them to speak whenever they feel compelled to. What this says to female students is that their voices matter less, or that they are expected only to speak when they have something insightful to contribute. They are experiencing literal silencing from both male students and their teachers.

This is also demonstrated through another phenomenon that Sadker and Sadker discovered during their research in classrooms across America. Teachers are less likely to call on female students who have their hands raised than male students. This is an easy metric to track and, to me, yielded surprising results,

In the typical classroom we found that approximately 10 percent of students are green-arms [enthusiastic participators] and 70 percent are nominal ... Of course some boys are shy and some girls are assertive, but we found that male students are more often starts and female students are more often stifled. One researcher found that for every eight star-boys there is only one star-girl (48). 
Again, because teachers have lower expectations of male student participation, they attempt to reward hand-raising (for both participatory and disciplinary reasons) by calling on them. This is traditional practice for teachers, as students who are less likely to participate should be rewarded for their participation, but not at the expense of female students. Certainly, it would not be a difficult behavior to correct, and it could have a large impact on female students. Sadker and Sadker found that girls are the third most likely to receive teacher attention after white males and minority males. The least likely to be acknowledged are minority females (50). The consequence of not changing this behavior is a continuation of the cycle of suppression of the female voice. The more often female students raise their hand and don't get chosen, the less often they will take the chance to raise it in the first place. Female students are already faced with tons of external factors that influence their self-esteem; educators could make a positive impact on this by simply including them in the conversation more frequently.

Sadker and Sadker found the same issue in time spent with male versus female students in elementary school classrooms. Teachers walking around the room while students worked independently would stop at tables with male students to correct their work or praise their work, but were more likely with female students to only glance at their work or simply say "good work" without looking at their work at all (12). This is another example of how teachers can inadvertently silence the female voice in the classroom. The female student does not have the opportunity to ask a question of her teacher while she is stopped at her desk, because she never stops at her desk. The invisibility of the female student is simply confirmed by the teacher at this point in her instruction, "Each time the teacher passes over a girl to elicit the ideas and opinions of boys, that girl is conditioned to be silent and to defer" (13). This continues to develop a lack 
of self esteem for female students as well as a lower desire to participate, and develops the skills of male students.

The same study out of George Washington University also found that women are more likely to use qualifying language like "I don't know if this is right but..." or "This could be a dumb question but...". For some reason, men are far less likely to feel the need to qualify their statements with these dependent clauses. While the study didn't go on to explore why this phenomenon exists, I would argue that the young women feel this need because of years of conditioning from other students and teachers that they can quell potential embarrassment of being wrong or asking a "dumb" question by simply demonstrating that they know this may be the case. Again, women, faced with decreasing self-esteem over time continue to use this language in order to stop any potential embarrassment in the classroom. The worse result, of course, is not speaking at all. When and how can educators work to empower these women with the desire and ability to make claim without preemptively disqualifying it?

If women continue to use this language without correction, it carries into their adult lives which influences not just themselves but the community at large. A broad issue with female empowerment is how women can integrate themselves into STEM fields and higher ranking positions in business. Naturally, there are many external elements that cause these issues in gender equality, but empowering women with a voice in a safe space like a high school classroom can make a large impact on this problem. Women can't get promoted if they say "I don't know you agree, but I think I've demonstrated my skills to be qualifying for a raise this year." They need to feel the power to say "I deserve this raise/promotion/job/right." If teachers aren't able to give them this power from the beginning of their education into their adult lives, 
where will they learn? I feel strongly that it is not only in the best interest of teachers to correct this behavior, but is a duty of educators in favor of promoting gender equality overall.

Even though women perform better than male students in education, there is a deeper impact of silencing the voices of half the American population. The Oregon Department of Education reports that the 2013-14 graduation rate for students entering school in the 2009-10 school year (4 year track) was 76.4 percent over all. However, female students were at an 80.08 percent rate of completion and male students fell at 72.97 percent (2015). Further, in 2014, the Pew Research Center reported that the rate of women attending college had risen to 71 percent in 2012 (up from 61 percent in 1994), while male enrollment rates remained stagnant at 61 percent (Lopez and Gonzalez-Barrera). Finally, the National Center for Education Statistics reports that female students have consistently held higher GPAs than male students since 1990 (NAEP 1990-2009). Despite the fact that women make up more high school graduates, more college students, and have higher overall GPAs, this is not reflected in the workforce. There are distinctly fewer female scientists (41\% of science and engineering PhDs go to women), CEO's (women hold 23 of the Fortune 500 CEO positions), and politicians (women make up 18.5\% of Congress) (Catalyst, 2015; Hobbs, 2015; National Women’s Political Caucus, 2013). The irony of this is that the majority of the teaching population is made up of women. How are female teachers being trained to continue this cycle of invisibility themselves? Women's voices clearly continue to be silenced into the schools of education cycles back into the classrooms.

\section{Instruction:}

Overall, the priority of this project is the production of a year-long course syllabus that focuses on the inclusion of the female student. The lesson plan will include not just required 
reading throughout the year, but also plans for assignments, class discussion, and suggestions for being more gender inclusive during instruction. Required reading will include modern classics like the work of Toni Morrison, but also more contemporary literature in the hope of connecting students to the works. Authors like ZZ Packer provide a cross-cultural reference point as she writes short stories about being a queer woman of color. More and more, contemporary texts like The Hunger Games are working their way into the curriculum and I hope to continue this trend. The key, however, is that it is not productive to simply change the chosen texts. Teachers have to also be trained to discuss these pieces in such a way that they serve the intended purpose. How can teachers use these texts as a tool to provide students with a more well-rounded understanding of gender without systematically oppressing any gender?

Discussion is a fundamental element of Language Arts instruction. Unfortunately, this element of instruction is not able to function at the capacity it should as teachers make way for standardized testing and required benchmarks from the Common Core, which are mostly focused on writing and comprehension. However, it is my firm belief that students should complete high school with the confidence and knowledge to discuss texts verbally with their peers. Course discussion must allow itself to be focused (but not exclusively) on the topic of gender and the female experience. It is one of my objectives to educate male students as well on the issues of gender so they can distribute this knowledge and feel comfortable discussing the topic outside of class. This model will not help any students if the focus turns from a primarily male-based curriculum to a primarily female-based one. If equality is my mission, it is important to make sure that lesson planning doesn't in turn disenfranchise the other half of the class. Part of this, however, must include helping male and female students navigate the complicated and sensitive 
topic that is gender in the classroom. The teacher must not only foster a safe space for discussion, but also be the provider of the necessary tools. Students must learn the appropriate terms for discussing gender in a respectful manner while still feeling like they can be candid with their thoughts. This is a difficult role for the instructor to play, but it is certainly attainable with commitment, training, and practice.

It will be important to note that teacher training will be a major portion of ensuring discussion works effectively in this way. Many of the microaggressions and "hidden curriculum" models I have already mentioned need to be addressed. We have all heard the phrase "actions speak louder than words," and this is incredibly true in this scenario. Even if teachers were provided with a perfect lesson plan and curriculum, it could be completely undone by small, inadvertent actions performed by instructors. Teachers will be required to provide equal time with both men and women in the classroom. This could mean keeping a mental (or physical) tally of who has been called on in the class and simply being aware of the way that they are or are not favoring one gender in class discussion. Further, it will be important to focus on preventing interruption and empowering students by correcting qualifying language as much as possible. This could be something as simple as stopping the behavior when it is seen, for instance, "Make that claim again, but without saying 'This could be wrong." If we can recognize that these issues are not conducive to the learning environment, we can begin to correct the problem. Female empowerment can be accomplished though involved instructor facilitation. In order for class discussion to work properly, female students much be allowed and encouraged to speak. 
Assignments will follow a similar model, allowing students freedom of expression and a safe space to discuss topics of intersectionality in all ways. Writing prompts may include topics of gender and will encourage students to really reach for difficult topics as much as possible. Writing skills will also be developed through creative writing opportunities as autobiographical writing has been shown to be empowering to the author. While focusing on discussion can be a beneficial aspect of improving the English classroom, writing is an element that can't be ignored in favor of verbal dialogue. Students need to be confident and proficient in writing when they graduate in order to succeed in being accepted into universities, be competitive in their college careers, and be prepared for the work force. Language Arts instructors have the unique responsibility of teaching not just literature but writing, vocabulary, and often many aspects of history. Most of the time, students' writing skills cannot be fully developed by exclusively writing about literature. Students need to be educated on expository, narrative, and persuasive writing as well. Each of these can be modified to empower students' voices. Students can be found most vulnerable through writing, and this can serve as a very empowering opportunity. Narrative essay writing is perhaps the most empowering form of writing for all students, but can be effectively practiced in such way that teaches students about gender experiences. Narrative essay writing is also cathartic for many students (and adults) and can provide an outlet for thoughts that young women may not feel comfortable discussing out loud or with peers. This can be carried further by asking students questions that force them to consider gender topics. For instance, students could be asked to write an essay that asks them to answer the question, "What if you were born a different gender than you are? In what ways do you think you would be different or the same?" Asking questions like this not only encourages students to think about he 
complex topic of gender and how it shapes our lives, but also about their own gender identities and how that informs their life experience. There is no doubt that many advanced and intellectually mature students will have already grappled with this topic, but discussing these topics with all students can also serve to open students to things that they may not have understood or considered previously.

Personal essay writing also provides a practical function during college application season. The personal statement is becoming more and more important in the admissions process. If students (particularly female students) are comfortable and proficient in writing about themselves, they will be more competitive to admissions boards. Autobiographical writing is also empowering to women because of the access it provides the student to her own voice. She is able, through her writing, to take ownership of her own experiences, identity, and voice. That is why it is important as educators to be cautious when critiquing this work. Students must feel comfortable sharing their life experiences with their teachers in order for them to be truly honest with themselves in their writing. However, teachers have an obvious obligation to critique work in a way that seeks to improve the writing of their students. It is a fine line that must be treated delicately.

The key, then, is to really give proper attention to each student's work and how it can be improved. Grading practices are extremely difficult to consider in reference to gender. Clearly, teachers must remain unbiased in their grading practices; there are proven gender biases in hiring that can be easily applied to grading practices. A proficiency based grading model is a more impartial system for all genders as well as race, socioeconomic class and other cross-cultural students. In this model, students are graded not on the classic "total points" system, but based on 
their level of proficiency in various categories. What this accomplishes is students taking ownership of their learning and the process that is involved. Students, rather than having to complete several small assignments in preparation for a larger assignment or test, are allowed to decide what they would like to do in order to prepare. Some students are aware that they require more practice or preparation, and many students know they can be successful and can focus their time on other classes or activities. This model also changes the language around students' learning. Rather than asking "How to I get my grade up to an A in this class?," they are offered the choice to ask questions like "How do I 'exceed' in the category of conventions in this essay?". Students are allowed to take ownership of their work, and are given extremely specific feedback and opportunities to improve.

There is no doubt that much can be done at the administrative and state level to improve the female experience in the high school classroom. From improving the reading lists to providing teacher trainings on topics of gender and intersectionality. However, teachers can make many small changes in their own lesson planning models that can serve the same purpose. Even without support from the administration, teachers can begin to change the way they teach female students even if they can't change what they teach. Teachers have an opportunity to be facilitators for change in the field of education when it comes to gender and cultural competency. The changes I have suggested here would make a large impact on female and male students because they would be empowered with the knowledge to discuss this topic in a respectful and productive manner. Making these changes could also change a young girl's life if the support she feels from her teacher turns into the confidence to enter a predominantly male 
field, run for office, or just own her identity. The impact could be substantial, and the changes are small. 


\section{Advanced Freshman English Syllabus}

Welcome to Advanced Freshman English! This class will be utilizing the Common Core State Standards to develop your skills in reading, writing, and discussion. The theme of this class is voice so be prepared to develop your own voice and be respectful of the other voices around you.

The texts we will read this year are:

The Hunger Games - Suzanne Collins (Summer Reading)

Fahrenheit 451 - Ray Bradbury

The Joy Luck Club - Amy Tan

Poetry:

"Women" - Alice Walker

"Lift Every Voice and Sing” - James Weldon Johnson

"We Grow Accustomed to the Dark" - Emily Dickinson

"I Am Offering this Poem" - Jimmy Santiago Baca

The Book Thief - Markus Zusak

In addition to these works, you will also have an opportunity to complete independent reading throughout the year.

Grading:We will be focusing on 10 Common Core State Standards this year in order to best prepare each of you for the Smarter Balanced Assessment as well as the rest of your time as students in high school and college. Each student is capable of meeting or exceeding each of these standards this year.

\begin{tabular}{|l|c|l|}
\hline \multicolumn{1}{|c|}{ Proficiency Level } & Mark & \multicolumn{1}{c|}{$\begin{array}{c}\text { Description: Student } \\
\text { demonstrates the following: }\end{array}$} \\
\hline Exceeds & E & $\begin{array}{l}\text { Advanced understanding/ } \\
\text { application of the standard }\end{array}$ \\
\hline Meets & M & $\begin{array}{l}\text { Solid understanding/ } \\
\text { application of the standard }\end{array}$ \\
\hline Nearly Meets & N & $\begin{array}{l}\text { Gaps in understanding and/or } \\
\text { partial application of standard }\end{array}$ \\
\hline Beginning & BG & $\begin{array}{l}\text { Shows minimal } \\
\text { understanding/application of } \\
\text { the standard }\end{array}$ \\
\hline Not Attempted & N/A & $\begin{array}{l}\text { No attempt made on the } \\
\text { standard }\end{array}$ \\
\hline
\end{tabular}


You will get TWO opportunities to demonstrate your understanding of each standard. Your overall score for each standard will reflect your growth. If you improve on the second attempt, that score will become their overall score. However, if you regress, the overall score will be an average of the two attempts, or the score that is demonstrated twice. For example, if you earn an $\mathrm{E}$ (Exceeds) on the first attempt, but only M (Meets) on the second attempt, the final grade will remain a Meets, as that is the highest score you demonstrated twice.

*You may resubmit one essay at the end of the semester in order to meet any of the writing standards; however, you will not be able to exceed any standards on the resubmission. (Essays must be turned in within the given one week window).

\section{Final Grades Determination:}

\begin{tabular}{|c|c|c|c|c|}
\hline A & B & C & D & $F$ \\
\hline $\begin{array}{l}4 \text { Exceeds } \\
6 \text { Meets } \\
\text { No nearly meets } \\
\text { or beginnings }\end{array}$ & $\begin{array}{l}7 \text { Meets or } \\
\text { Exceeds } \\
3 \text { Nearly Meets } \\
\text { No Beginnings }\end{array}$ & $\begin{array}{l}\text { No more than } 1 \\
\text { Beginning }\end{array}$ & $\begin{array}{l}\text { No more than } 3 \\
\text { Beginnings }\end{array}$ & $\begin{array}{l}4 \text { or more } \\
\text { Beginnings } \\
\\
\text { Insufficient } \\
\text { Evidence: } \\
\text { Standards not } \\
\text { attempted. }\end{array}$ \\
\hline
\end{tabular}

\section{Common Core Standard Grade 9 Language Arts}

"The Common Core asks students to read stories and literature, as well as more complex texts that provide facts and background knowledge in areas such as science and social studies. Students will be challenged and asked questions that push them to refer back to what they've read. This stresses critical-thinking, problem-solving, and analytical skills that are required for success in college, career, and life."

\section{Reading:}

\section{Literary Text}

1. Determine the meaning of words and phrases as they are used in the text, including figurative and connotative meanings; analyze the cumulative impact of specific word choices on meaning and tone (e.g., how the language evokes a sense of time and place; how it sets a formal or informal tone).

2. Determine a central idea of a text and analyze its development over the course of the text, including how it emerges and is shaped and refined by specific details.

3. Compare works that express a universal theme, and provide evidence to support the ideas expressed in each work. 
4. Analyze how complex characters (e.g., those with multiple or conflicting motivations) develop over the course of a text, interact with other characters, and advance the plot or develop the theme.

\section{Discussion}

5. Propel conversations by posing and responding to questions that probe reasoning and evidence; ensure a hearing for a full range of positions on a topic or issue; clarify, verify, or challenge ideas and conclusions; and promote divergent and creative perspectives.

\section{Vocabulary}

\section{Writing}

6. Determine or clarify the meaning of unknown and multiple-meaning words and phrases based on grades 9-10 reading and content, choosing flexibly from a range of strategies.

\section{Narrative}

7. Write narratives to develop real or imagined experiences or events using effective technique, well-chosen details, and well-structured event sequences.

\section{Informative/Expository}

8. Write informative/explanatory texts to examine and convey complex ideas, concepts, and information clearly and accurately through the effective selection, organization, and analysis of content.

a. Introduce a topic; organize complex ideas, concepts, and information to make important connections and distinctions

b. Develop the topic with well-chosen, relevant, and sufficient facts, extended definitions, concrete details, quotations, or other information and examples. (Ideas \& Content)

c. Use appropriate and varied transitions to link the major sections of the text, create cohesion, and clarify the relationships among complex ideas and concepts. (Organization)

d. Use precise language and domain-specific vocabulary to manage the complexity of the topic. (Word Choice)

\section{Conventions}

9. Demonstrate command of the conventions of standard English grammar and usage when writing. (Conventions) 10. Use various types of phrases and clauses to convey specific meanings and add variety and interest to writing. (Sentence Fluency)

\section{Life Skills: Career Related Learning Standard}

Organization: plan, organize, and complete practice \& assessments accurately and on time. Personal Management: exhibit work ethic, responsibility, and the ability to be responsible and dependable. Teamwork Skills: participate cooperatively, productively, and respectfully in teams to complete to tasks. Students will only be able to MEET this standard, as it is impossible to exceed what is already expected. 
6 Week Unit Plan:

The Hunger Games and Narrative Essay Writing

\begin{tabular}{|c|c|c|c|c|c|}
\hline & Monday & Tuesday & Wednesday & Thursday & Friday \\
\hline 1 & $\begin{array}{l}\text { First Day of Class: } \\
\text { - Present a "Me in } \\
\text { a Box" } \\
\text { - Class } \\
\text { Expectations } \\
\text { - Syllabus/Grading } \\
\text { * Summer Reading } \\
\text { Assignment Due }\end{array}$ & & $\begin{array}{l}\text { - Hunger Games } \\
\text { Vocab } \\
\text { Assignment } \\
\text { (Group) }\end{array}$ & & $\begin{array}{l}\text { * Vocab Test } \\
\text { - Introduce } \\
\text { Independent } \\
\text { Reading } \\
\text { - Lesson on } \\
\text { Propaganda }\end{array}$ \\
\hline 2 & & $\begin{array}{l}\text { - Literary } \\
\text { Analysis } \\
\text { Lesson } \\
\text { - Class } \\
\text { Discussion: } \\
\text { Female } \\
\text { Characters in } \\
\text { Literature }\end{array}$ & & $\begin{array}{l}\text { - Socratic } \\
\text { Circle } \\
\text { Hunger } \\
\text { Games } \\
\text { Discussion }\end{array}$ & \\
\hline 3 & $\begin{array}{l}\text { - Introduce } 8 \\
\text { Paragraph Essay } \\
\text { - Read "The } \\
\text { Lottery" out loud } \\
\text { in class }\end{array}$ & & $\begin{array}{l}\text { - Practice } 8 \\
\text { sentence } \\
\text { paragraph as a } \\
\text { group with "The } \\
\text { Lottery" }\end{array}$ & & $\begin{array}{l}\text { * Vocab Test } \\
\text { * } 8 \text { Sentence } \\
\text { paragraph for } \\
\text { THG Due }\end{array}$ \\
\hline 4 & & $\begin{array}{l}\text { - Introduce } \\
\text { Narrative Essay } \\
\text { Assignment }\end{array}$ & & $\begin{array}{l}\text { - Lesson on } \\
\text { Descriptive } \\
\text { Language } \\
\text { - In class } \\
\text { writing using } \\
\text { descriptive } \\
\text { language }\end{array}$ & \\
\hline 5 & $\begin{array}{l}\text { - Lesson on } \\
\text { Openers/ } \\
\text { Grabbers } \\
\text { - Play Storytelling } \\
\text { Telephone }\end{array}$ & & $\begin{array}{l}\text { - Lesson on } \\
\text { Dialogue } \\
\text { - Dialogue Free } \\
\text { write and } \\
\text { "plays" Activity }\end{array}$ & & $\begin{array}{l}\text { * Vocab Test } \\
\text { - Workshop } \\
\text { Rough Drafts }\end{array}$ \\
\hline 6 & & $\begin{array}{l}\text { - Storyboarding } \\
\text { activity } \\
\text { - Organization } \\
\text { Lesson }\end{array}$ & & $\begin{array}{l}\text { - Read Around } \\
\text { of Narrative } \\
\text { Essays } \\
\text { - Reflection } \\
\text { Worksheets }\end{array}$ & \\
\hline
\end{tabular}




\section{Lesson Plans for Weeks 3 and 4:}

90 Minute Periods, A/B Schedule

Monday (7:50 - 9:20)

7:50 - 8:00

Get settled, attendance, Warm-up (Good news, Birthdays, Weekend)

8:00 - 8:20

Introduce week's vocabulary, read words and example sentences out loud, distribute worksheets.

8:20 - 8:40

Introduce the 8 Sentence Paragraph (Rough overview). Explain Concrete Details and Commentary. Distribute CD, COM COM worksheet.

8:40 - 9:20

Read "The Lottery" out loud (consider popcorn reading), distribute class copies to be kept in the room. Brief discussion (initial reactions) if time permits

\section{Wednesday}

7:50 - 8:00

Get settled, attendance, Warm-up (Good news, Birthdays, Weekend)

8:00 - 8:10

Free write/brainstorm writing about "The Lottery."

How does it compare to The Hunger Games?

How is the portrayal of women different in the story vs. the novel?

Would you want to live in this society?

What is the theme of this story?

8:10 - 8:30

Snowball discussion on questions answered before.

\section{8:30 - 8:40}

Group discussion to determine thesis statement about "The Lottery." What is the theme?

\section{8:40 - 9:00}

Small groups or table groups each work to find a concrete detail and write to sentences of commentary to support the class thesis.

9:00 - 9:20

Put together the final paragraph as a class. Assign an 8 sentence paragraph for The Hunger Games. 


\section{Friday}

\section{7:50 - 8:00}

Get settled, attendance, Warm-up (Good news, Birthdays, Weekend, Turn in assignment

\section{8:00 - 8:30 \\ Vocabulary test and silent reading \\ 8:30 - 8:40}

Explain Hunger Games Game: 5 members of the class are chosen at random to represent the elite class while the rest of the class remains in poor "districts." Each district is distributed a certain amount of resources and rules regarding women, work, etc. Cards are drawn at random to demonstrate how systems of oppression and dominance effect the lowest classes and minorities in a society. Tributes can be chosen from the "districts" who move into the elite class if they win a coin toss tournament.

\section{8:40 - 9:20}

Play Hunger Games game, dismiss.

\section{Tuesday}

\section{7:50 - 8:00}

Get settled, attendance, Warm-up (Good news, Birthdays, Weekend)

\section{8:00 - 8:20}

Full class discussion about Hunger Games simulation. How did it make us feel? What were the implications of the system in place? Who benefited the most? Who benefited the least?

\section{8:20 - 8:30}

What makes a good narrative essay? Short discussion and assignment handed out: Tell the story of your high school experience. (Assignment attached.)

\section{8:30 - 8:50}

Read good examples of narrative essays from past students or professional writers. 8:50 - 9:20

Brainstorming activities:

Clustering (10 min) - Demonstrate using a web to brainstorm topic ideas

Free-writing (10 min) - Have students write whatever comes to their mind for 10 straight minutes.

Outlining (10 min) - Demonstrate how to outline a story and the many ways to break up an essay (chronological, by topic, by character, etc.) 


\section{Thursday}

7:50 - 8:00

Get settled, attendance, Warm-up (Good news, Birthdays, Weekend)

\section{8:00 - 8:10}

What does it mean to show and not tell? Short discussion.

8:10 - 8:30

In small groups, find 3 examples of excellent descriptive language in The Hunger Games. 8:30 - 9:00

White board activity: list descriptive words in columns, then as a group find other ways to explain what they describe by showing instead of telling.

9:00 - 9:15

Free write on your own essay (or another new piece, it's just for practice) but choose something to "rewrite" using better descriptive language.

9:15 - 9:20

Exit Tickets - How are things going? Are you feeling prepared to write your essay? 


\section{Assignment: The Narrative Essay}

Description: When I was a Freshman in high school, I was certain that I would be a valedictorian when I was a graduating senior. I had a lot of expectations about what high school would be like for me, and I'm sure you do too. For this essay, I would like you to write a narrative (story) about what your high school experience will be like. You can be as creative as you like, or think of it as a means of goal setting. Here are some questions to consider:

- Describe yourself. You will need to have a sense of who you think you will be before you can determine how you will interact with the world around you.

- What influences you for the next four years? Your parents? Your friends?

- What do you want to accomplish?

- What do you want to avoid?

You need not answer all of these in your essay, but be considering the content you want to include.

Audience: Your colleagues in this class and I are your audience. Remember the relative ages of your audience when determining what they might know.

Writer's Persona: This is a personal essay so feel free to let your voice through in your writing. It should sound like you, but remember grammar and conventions!

Length: 4-5 pages

Writing Issues: Narrative writing, content formulation, dialogue, details, event sequencing. 


\section{Explanation of Curriculum Decisions}

Texts:

What I have provided here is a selection of a course plan that I find to be more gender inclusive than the traditional model. I have demonstrated texts I would use throughout the year as well as the grading system for this class. From there I broke down a six week unit plan that includes both working with text but also a writing assignment. Finally, I broke down a week of lesson planning as I imagined these lessons would be carried out. As mentioned previously, many of the changes that I would suggest begin with the behavior of the instructor and would need to come from teacher training. Here I have simply provided an example of a class that begins to tackle some of these issues, and would need to be taught by a teacher who has been trained on this topic.

First, the course is based around six texts that are evenly dispersed throughout the year of school into six-week units. My first choice, The Hunger Games, I chose as a Summer reading assignment. I think this is a text that many students (particularly female students) have already read and would take the time to revisit over the summer before high school. Also, because students are obviously not monitored over the Summer, it seemed important to choose a text that would be more enticing to the students because of its readability, and mainstream exposure. I have already discussed the ways in which The Hunger Games is an excellent choice for the purpose of female empowerment, but I will mention again that this text is incredibly unique in its treatment of female characters.

The next texts I chose were also listed on the Common Core list of suggested texts for grade 9. I chose Fahrenheit 451 even though it isn't known for its recognition of women but 
because of its focus on voice, which is a central theme to the topic of female empowerment. I hope that a discussion on this text will lead students to consider the ways in which voice is affected by media, government, and peers and apply that knowledge to their understanding of the female experience. I think this choice demonstrates that a text doesn't necessarily need to have a female author or protagonist in order to facilitate a discussion about empowerment.

The Joy Luck Club appears on the syllabus because of the text's attention to intersectionality. The characters in this text are not just women but also Asian-American. This text would be used to show students the experience of being a member of multiple underrepresented groups in America, as many students will be able to relate to this experience. I also think The Joy Luck Club is an excellent choice because Amy Tan's comical voice and her use of modern language. These things will help the students be more engaged in the text as a opposed to older texts which can feel stuffy and difficult to relate to (even as an adult). There is also an opportunity to include some of Tan's short stories to compliment the novel and inform our understanding of the author.

The fourth reading unit in my plan is a poetry unit. Many students are naturally drawn towards poetry over novels and for many students poetry can seem more approachable and less taxing and time consuming. Through careful instruction, I will demonstrate to my students how to complete a close reading of the poem, how to analyze poetry, and hopefully instill in them a desire to write or explore other poetry on their own time. The poems I have chosen are all either written by female authors or wrestle with the topic of voice. This poetry unit would definitely be accompanied by a poetry writing unit in an attempt to give students an opportunity to explore a different kind of writing voice outside of narrative and expository writing. 
The next book on my syllabus, The Book Thief, has several purposes, the first of which is to provide a historical element to the class. Until this point, students have only been exposed to fictional worlds that we can only speculate are meant to represent or critique certain time periods. This text takes place in WWII and provides a narrative of a female journey through Nazi Germany. This novel also has themes about voice, access, and oppression, all of which are important topics to explore at the high school level. Finally, I think this text is a good choice because of it relatively recent publication (2005), and its recent popularity due to a film adaptation.

The final unit of the year involves a "choose your own adventure" model of a reading unit. Here I plan to empower student voices by allowing them to choose the final book they would like to work with for the year. Students will be asked to choose a text they believe reflects the concepts of voice and empowerment that we have been discussing throughout the year. By this point, the idea is that students will be experts in identifying texts of this nature. By giving students a choice, they are gaining some sense of control over the class they are a part of, as well as an opportunity to study something that they are genuinely interested in.

My hope is that these texts, when taught together, will develop the skills of students to identify and discuss issues of voice and empowerment as they pertain to women and other less privileged members of society. By giving them an opportunity to explore texts that take place over multiple historical eras, as well as texts that grapple with issues both fictional and historical, students will develop their skills in cultural competency and social justice as well as their skills in literary analysis, writing, and discussion.

\section{Unit Plan:}


Day 1: The first day of class naturally follows a model of introducing students to the teacher, discussion of expectations, and explaining the syllabus. Students can be empowered on this day by being involved in the development of expectations by creating an agreed upon class constitution or class guidelines. If students feel like they have ownership over the rules they have agreed to follow, they will be more likely to follow them.

Day 2: Assuming students have already read The Hunger Games over the Summer, this day focuses on Common Core Standard 1 listed on the syllabus. Students will be asked to work in groups to find words in the novel that describe a particular emotion, define the word, write an example sentence using the word, and draw a picture that represents the tone of the words. Day 3: This day will be used to wrap up the projects from the previous day. Students will also take the first of bi-weekly vocabulary tests (Common Core Standard 6). Instructor will introduce independent reading assignment (one book of outside reading per 6 week unit). Finally, students will given a prepared lecture about propaganda as it pertains to The Hunger Games and a discussion will be led.

Day 4: On this day students will be introduced to literary analysis, which fulfills Common Core Standard 2. This is a crucial day for the instructor as students will need to foster and develop these skills over the course of the year. The class will round out with a group discussion about female characters in literature (Common Core Standard 4). I chose to have this discussion because of the context presented in The Hunger Games as well as its relevance to the class theme as a whole. As I have already demonstrated, these types of discussions are both rare and necessary. 
Day 5: On this day I chose to facilitate an all-class discussion of The Hunger Games (Common Core Standards 5 and 2). I feel that spending a full class period on this topic will allow students to fully understand the way a discussion of literature is meant to be carried out. I would consider using the "fish bowl" method of discussion here (two concentric circles are formed, the inner circle is involved in the discussion, the outer circle is responsible for listening and reflecting then the circles are switched). This method is effective for ensuring student participation as well as giving students an opportunity to consider what makes a productive discussion.

Day 6: (The following 5 days are outlined in detail in the included lesson plan.) I chose to use the "8 Sentence Paragraph" for this class because of its clarity and practicality for literary analysis. I have found that this method (A paragraph of an introductory sentence, a concrete detail (CD) from the text, two sentences of commentary (COM), another concrete detail, two more sentences of commentary, and a concluding sentence) is effective, easy to learn, and has benefitted me even in my college career. I also chose to include the reading of "The Lottery" by Shirley Jackson (Common Core Standard 3) on this day because it pertains to our discussion about girls and women in literature from the previous class as well as to The Hunger Games in thematic elements.

Day 7: This day will focus on free-writing, discussion, and formal writing. The empowerment of the student comes from an opportunity to express their understanding of the text in three separate ways rather than forcing them to only analyze text in one determined way. The "snowball" discussion (students begin by talking to one other person, the groups of two then become four, etc) is effective because it benefits students who work best in small groups, and students who thrive in large groups. 
Day 8: This day is reserved for wrapping up the unit on The Hunger Games, putting into context the issues of social justice, and having a little fun. The game is meant to randomly select students to administer the "Hunger Games" in the classroom in order for student to experience “first hand' through simulation what it feels like to be systematically oppressed. Ideally, at the conclusion of the game, students will be able to discuss the how these issues make them feel on a personal level and will then carry these opinions into real life applications.

Day 9: This day comes with the assignment of the first full essay of the year. I chose to begin with a narrative essay for two reasons. The first is that narrative writing seems to be more approachable to the student than expository. Secondly, autobiographical writing has been proven to be incredibly empowering for the female student. In this way a student is able to find her voice in text and take ownership of her own words and experiences. I also see this assignment as an opportunity for goal setting for students. As they imagine where they will be at the end of their high school experience, I can try to develop ways to help them reach those expectations. Day 10: This unit on descriptive language is a classic approach to teaching students to "show not tell" in their writing. I have given students an opportunity to correct their own writing during the class period, in order for them to have access to the instructor during this crucial revision process. I have also incorporated on this day an "Exit Ticket" on which students can write whatever they want (not anonymously) about how they feel they're doing in school, personally, or at home. It is essentially an opportunity for the instructor to check in with students in a noninvasive way in order to better understand where students are coming from.

Day 11: The remainder of this unit focuses on preparing the student to write an excellent narrative essay. This day is specifically interested in teaching opening sentences/grabbers. The 
activity I've included (storytelling telephone - students each write the next sentence of a story based only on the sentence before it) is just a fun way to show how the beginning of the story can go in any direction.

Day 12: This is a day to focus on dialogue in storytelling. Students will be given an opportunity to "take the stage" with an activity in which groups write a series of dialogue, and other groups act out the dialogue for the class. I chose this activity because it develops the skill of writing dialogue but also gives students a chance to see their writing in action in a literal sense, as well as give students an opportunity to develop presentation skills and comfort in front of groups. Day 13: This day is reserved for workshopping rough drafts. Students will be paired with at least three different students over the course of the class period. Student responders will be required to answer specific questions about what they're reading in order to be the most effective at providing constructive feedback. The collaborative process of writing is crucial because writing is such a vulnerable process. Hearing feedback from peers can be much less difficult than hearing it from a teacher. Also, developing skills of writing response is useful for students so they can learn to edit and revise their own work.

Day 14: On this day students will have determine whether or not their story is organized in the best possible way. The activity is a storyboarding project in which students must break down their narrative into six squares, like a comic strip. The idea is that the story should still flow naturally. Students can also cut apart the squares and rearrange them in order to better organize their story.

Day 15: This day might be the most important for the purposes of student empowerment and writing. Students will be presented with an opportunity to do a "read around" of their narratives. 
The opportunity of students to share their writing with the class gives other students exposure to different perspectives and experiences. The writing reflection process is also crucial. Students will respond to questions about their writing like "My favorite part about this piece is.." and "I wish I had more time to work on..." This process helps students take ownership of their work as well as reflect on the process as a whole, rather than just the final project.

\section{Conclusion:}

I was inspired to write about this topic because of my own personal experiences in the public high school system in the state of Oregon. I had always felt as a female student that I was frequently silenced, erased, and ignored as a less privileged member of the community. Over time, and through my undergraduate studies, I discovered that not only were my feelings completely valid, but that they were completely preventable. When I began this research, I sought to determine if there was a problem with female students and the way they were being represented and treated in high school classrooms, and then sought to discover what could be done to correct the problem.

What I found was that there is absolutely an issue with female students in the high school classroom. Although it seems on the surface that women are out-performing men in high schools (and more and more higher ed), there are much deeper rooted issues with the way that women experience the learning process in public education systems. What I found through research was that despite their "success" in school, women graduate less likely to be successful in the real world. After twelve years of public schooling, women do not feel empowered to take on the male-dominated world, and seem to be unable to penetrate the male-dominated workforce The 
problem lies with years of conditioning that women and men are meant to fulfill certain roles (in terms of subject areas of study), and that women require less attention than men because they are more well-behaved overall. This leads to less instructor attention and thus, a less well-rounded education. Because nearly every student in America attends a public school for twelve years, nearly no one is free from these minor forms of oppression that add up to a lifetime struggle for women in terms of wage, achievement, and progress.

What I found after I identified this problem was that no one had attempted to correct the issue in a meaningful way. In fact, most of the research I could find on this subject was dismally outdated considering the significance of the problem. What I attempted to do when I discovered this was to provide my own solution based on the specific elements of the issue as a whole. I found that some of these problems could be corrected by rewriting the curriculum that schools use in order to make them more gender inclusive, training teachers to recognize and avoid microaggressions, and encouraging student voices to be heard in many ways. From here I was able to construct what I consider to be a more gender inclusive curriculum, down to two weeks of minute by minute lesson planning. I then demonstrated how these corrections to the system applied to the issue at hand and specifically targeted issues of student empowerment.

If I had more time for research, there are a couple of things I would like to explore on a longer term basis. First, I would like to share this curriculum with other educators in public school systems and see if they notice a difference. What are they doing similarly or differently? I have limited access to what is happening inside the walls of the classroom, so I would love to explore some specific classrooms and see if other teachers are trying to tackle this issue, but aren't contributing to the literature on it. I would also like to do some primary research similar to 
that of Sadker and Sadker. I would love to collect and analyze the female voice directly. By recording class sessions, and then comparing female dialogue to male, I may be able to identify significant differences. Because most of the work on interruption and qualifying language was conducted on adults, I would like to demonstrate how this phenomenon is influencing the female high school student. Finally, I would be interested to see this lesson plan in action. Currently, everything I have written is based entirely on conjecture of what might help solve this problem. If I could implement this work into an actual classroom, I could track how or if these suggestions make a difference to the female student, the teacher, and the class as a group.

Through this research I have certainly determined that the ways we interact with young women has a lasting impact on their success later in life. Teachers often spend more time with these young adults than their parents do, so it seems that it is the responsibility of the institution to ensure that female students are leaving high school educated, empowered, and ready to contribute to society in a meaningful way. I feel that teachers have a responsibility to stop the silencing of the female voice in the classroom in the form of literature, student voices, and instruction. A change at the ground level would certainly make an influence on society as a whole. We owe it to young women and men to give them the best education they can possibly have, and these changes would certainly make a dent in reaching that goal. 


\section{Bibliography:}

Agatucci, Cora. "Writing Women in (to) the Curriculum." (1991).

The American Association of University Women Educational Foundation. How Schools Shortchange Girls. N.p.: American Association of U Women, 1992. Print.

Bender-Slack, Delane. "The role of gender in making meaning of texts: Bodies, discourses, and ways of reading." Feminist Teacher 20.1 (2009): 15-27.

Catalyst. Women CEOs of the S\&P 500. New York: Catalyst, April 3, 2015.

Cambron-Mccabe, Nelda, and Martha M. McCarthy. "Educating School Leaders for Social Justice." Educational Policy 19.1 (2005): 201-22. Web.

Davis, Chelsea. "Controversial Book Pulled from North Bend High Class." Coos Bay World. N.p., 19 May 2014. Web. 11 Dec. 2014.

Doey, Laura, Robert J. Coplan, and Mila Kingsbury. "Bashful boys and coy girls: A review of gender differences in childhood shyness." Sex Roles 70.7-8 (2014): 255-266.

Gilligan, Carol. "Teaching Shakespeare's Sister: Notes from the Underground of Female Adolescence." Women's Studies Quarterly 2nd ser. 19.1 (1991): 31-51. JSTOR. Web. 5 Dec. 2014.

Hancock, Adrienne B., and Benjamin A. Rubin. "Influence of Communication Partner's Gender on Language." Journal of Language and Social Psychology 34.1 (2014): 46-64. Influence of Communication Partner's Gender on Language. 11 May 2014. Web. 5 Dec. 2014.

Hobbs, Amanda. "How Nations Fare in PhDs by Sex [Interactive]." Scientific American Global RSS. Scientific American, 16 Sept. 2014. Web. 30 Apr. 2015.

Houck, Eric A. "Resource Distribution and Graduation Rates in SREB States: An Overview." Peabody Journal of Education 85.1, Education in the American South: Historical Perspectives and Contemporary Conditions (2010): 32-48. Oregon Department of Education. 29 Jan. 2015. Web. 10 Feb. 2015.

Jackson, Sarah M., Amy L. Hillard, and Tamera R. Schneider. "Using Implicit Bias Training to Improve Attitudes toward Women in STEM." Social Psychology of Education 17.3 (2014): 419-38. Web. 11 Dec. 2014.

King, Amy. "The VIDA Count 2013." VIDA Women in Literary Arts. N.p., 24 Feb. 2013. Web. 25 Jan. 2015 
Kohn, Terry M., and Educational Resources Information Center. An Investigation into the Awareness among High School Teachers of Boys' Reading Preferences and an Analysis of the Required Reading of Boys in the Lower Track. S.1.]: Distributed by ERIC Clearinghouse, 2002.

Moss-Racusin, C. A., J. F. Dovidio, V. L. Brescoll, M. J. Graham, and J. Handelsman. "Science Faculty's Subtle Gender Biases Favor Male Students." Proceedings of the National Academy of Sciences 109.41 (2012): 16474-6479. Web. 11 Dec. 2014.

Myers, D.G. "MLA Rankings of American Writers." Commentary Magazine. N.p., 26 Mar. 2012. Web. 25 Jan. 2015.

Oregon Department of Education. "Common Core Standards for English Language Arts." Common Core State Standards Oregon (2010): 1-17.Common Core Standards English Language Arts. Oregon Department of Education. Web.

Sadker, Myra, and David Sadker. Failing at fairness: How America's schools cheat girls. Simon and Schuster, 2010.

U.S. Department of Education, Institute of Education Sciences, National Center for Education Statistics, High School Transcript Study (HSTS), various years, 1990-2009

Whaley, Liz, and Liz Dodge. Weaving in the Women: Transforming the High School English Curriculum. Boynton/Cook Publishers, Inc., 361 Hanover St., Portsmouth, NH 03801-3912, 1993.

"Women in Congress." Statistics. National Women's Political Caucus, 2010. Web. 30 Apr. 2015. 